\title{
Muerte y Resurrección de César Vallejo
}

\author{
Espera del Viernes Santo
}

1.- Una aldea de la Cordillera de los Andes: peruanos tiene, con las otras de la misma región, afinidad tan íntima, que el viajero foráneo no verá al recorrerlas sino homogeneidad imperturbada. Las diferencias, si existen, no se entregarán cuando las miremos por primera vez. En mi recuerdo, Río Blanco, Acobamba, Palcamayo, Huallai, en la sierra del centro, me hundieron en el mismo silencio, la misma expresión estática, la misma soledad translúcida de Chincheros y Písac, aldeas del Sur. Las casas de adobe, los balconcitos salientes, frágiles, las paredes blancas, los techos de paja o tejas y las calles en cuesta empedradas toscamente, dan la apariencia externa de estas aldeas; una atmósfera agraria y pastoral las envuelve con la manta gris del sosiego.

En una de estas aldeas serranas del Departamento de La Libertad, en Santiago de Chuco, nació César Vallejo, el 6 de junio de 1893. Su infancia limpia, pobre, se prolonga hasta la muerte asida a la dulzura inmortal de la madre evocada con infantil patetismo. En las letras hispanoamericanas sólo Paula Albarracín, madre de Sarmiento, inspira a su hijo un retrato tan noble. Vallejo vierte en el suyo su congoja, su desvalimiento de hombre "agarrotado" por la injusticia de un orden social donde nunca logró ajustarse. Sarmiento evoca a su madre con orgullo, Vallejo con nostalgia de huérfano que no aprende nunca a guardarse del peligro de vivir. Por eso vive en espera de su viernesanto según la imagen más tenaz de su poesía, imagen asociada a la Crucifixión y 'muerte de Jesús. Cuando en 1918 dice en el poema "E1 poeta a su amada" 
que hay un viernesanto "más dulce que ese beso" y ve el límite temporal de su vida con profética certidumbre, sabemos que vive en espera de la muerte que había de llegar el Viernes Santo de 1938.

2.-De la formación de Vallejo nos da Antenor Orrego noticias abundantes en el prólogo de la primera edición de Trilce. Le presenta en el ambiente colonial, tradicionalista, de Trujillo, asistiendo a las clases de la Universidad y viviendo una bohemia ingenua en el grupo formado por José Eulogio Garrido, Macedonio de la Torre, Alcides Spelucín, Juan Espejo y Alfonso Sánchez Urteaga, hoy pintor orientado en la nueva peruanidad que Vallejo inicia en la poesía. Orrego le describe "bronceado y enjuto", personalidad enérgica que a veces sorprende con "dichos y hechos de inverosímil puerilidad". Comidas de cabrito y chicha en alguna vivienda india servidas por mozas acaso princesas de la estirpe chimú, o lecturas y recitaciones en la playa de Huamán -Darío, Nervo, Whitman, Verlaine, Paul Fort, Samain y Maeterlinck- encendían la imaginación y afinaban la sensibilidad de los adolescentes. Por la noche recorrían la ciudad provinciana, pensativos y silenciosos o con ruidosa alegría. E1 ambiente austero se fué penetrando de hostilidad. Muchachas sencillas acogían a los estudiantes, participando en sus diversiones. Ellos las bautizaban con nombres mitológicos. Vallejo llamaba a la suya Mitho y la describe más tarde en una de las más extrañas narraciones de Escalas melografiadas.

3.-No precisa Antenor Orrego qué "sentimental agravio" provocó los celos del poeta hasta llevarle a propósitos de caballeresca venganza con un "Smith and Wesson". Disuadido por sus amigos marcha al día siguiente a Lima, en donde permanece hasta que decide su viaje a Europa. Antes de partir va a despedirse de su madre a Santiago de Chuco. Allí se le aprisiona con fantásticas acusaciones y recibe uno de esos "golpes de la vida" tan fuertes, "que abren zanjas oscuras en el rostro más fiero". Un condiscípulo le traiciona para confirmar una culpabilidad inexistente. César Vallejo sale rehabilitado de esta sombría experiencia, después de seis meses de prisión. Muchos de los poemas de Trilce y de las confesiones y narraciones carcelarias de Escalas melografiadas, son páginas de su diario de prisionero. 
4.-En 1923 se ausenta a Francia. Lleva cuatro libros publicados: Los Heraldos negros (1918), Trilce (1922), Escalas melografiadas (1923), y Fabla salvaje (1923).

Difícilmente podrá describirse la vida de Vallejo en París, después de lo que Juan Larrea ha escrito con poético temblor y profunda intuición crítica. Leed la Profecía de América, donde se trenzan en emocionado haz patética biografía y exégesis lírica; donde se establecen con firmes soldaduras algunas afirmaciones sobre Vallejo que labran su estatua de arte para siempre. Entre estas uiltimas resumo las que me parecen más estrictas y aclaradoras:

Vallejo ha vertido a lenguaje hispánico el extracto planetario de La cordillera andina; no es un cantor, sino un instrumento de la poesía viva; su persona es encarnación ilustrativa del tema poético del mundo; acento embargado por la materia exclusiva del hombre.

5.-En 1928 hace su primer viaje a Rusia; en 1929 recorre toda Europa, visitando de nuevo a Rusia. Amplía en este último viaje sus estudios sociales. En diciembre de 1930 es expulsado de Francia. En ninguna de las notas biográficas que he leído se explica la causa de esta expulsión. Georgette Vallejo, la esposa del poeta a quien debo gran parte de la información vertida en estas páginas, no menciona el hecho.

6.--Reside Vallejo en España hasta 1932, año en que regresa a París. En España, por iniciativa de José Bergamín, Rafael Alberti y Pedro Salinas reedita Trilce (1930) y publica dos libros: artículos sobre Rusia bajo el título Rusia 1931 y una novela sobre el proletariado indígena del Perú en la explotación minera: El tungsteno. Esta novela ha sido traducida al alemán, al ruso y al francés. Selecciones de Trilce se han traducido al francés con una introducción de Pierre Lagarde. Rusia 1931 ha sido traducida al portugués. Amigos de Vallejo editaron en París el libro póstumo Pocmas humanos (1939).

7.--Madame Vallejo me comunicó en carta escrita en diciembre de 1937, que el poeta tenía terminados otros volúmenes inéditos de poesía, ensayo, teatro y cuentos. Uno de ellos, El arte y la revolución, estudia los problemas estéticos de nuestro tiempo. Pienso que estarán inclúdos allí los artículos "Poesía nueva", publicados en 
Amanta, número de noviembre de 1926, y el muy revelador "Autopsia del superrealismo", en Amanta, mayo de 1930.

8.-A1 principio de 1937, durante la guerra civil española, visitó a Barcelona y a Valencia. En el mismo año asiste al Congreso Internacional de Escritores en Valencia y Madrid. En ese año - para él de dramática actividad, de prisa en la creación poética - es nombrado secretario de la sección de la Asociación Internacional de Escritores para la Defensa de la Cultura; escribe los poemas del libro España, aparta de mi este cáliz y los Poemas humanos.

Muere de una dolencia misteriosa, un agotamiento febril cuya raíz física no encontró la medicina. Esto sucede en abril de 1938. Su cadáver fué acompañado al cementerio de Montrouge por gran numero de amigos y compañeros en letras.

9.-César Vallejo, en 1923, en el retrato puesto al frente de la novela Fabla salvaje, es un hombre joven de cabeza enérgica, cabellos densos, lacios, oscuros, peinados hacia atrás; frente comba de inusitada anchura. Los ojos indios, angostos, miran con mansedumbre melancólica; la boca grande, apretada con firme amargura, el mentón decidido, hacen pensar en algunas esculturas de hombres mochicas de hace seiscientos años.

E1 espiritual dibujo de Picasso que acompaña la edición de España, aparta de mí este cáliz, es de 1938. Es sin duda la interpretación picassiana del poeta, en su expresión ya distante, ensimismada de muerte. Los cabellos - leve sombra ahora- han retrocedido, dejando en la frente el movimiento ondulado de las punas de su tierra; el rostro entero se adelgaza hasta las lindes de inmediato acabamiento; la nariz se alarga, prominente entre los ojos, que ahora no parecen indios, sino universales, absortos en el dolor del mundo; los labios se aprietan aún, pero sin amargura, más bien con resignada sabiduría.

\section{Raíces de su poética}

10.-Andinismo.-El andinismo de Vallejo le aprisiona desde su nacimiento, de modo que su expresión es después, en el poeta, desdoblamiento natural de sí mismo. Cuando aparecen los poemas de Los Heraldos negros nace el neoindianismo estudiado en mi ensayo La literatura indianista en el Perí de hoy (1938). Lo pintoresco es 
desplazado por los fuertes escorzos de una naturaleza inédita hasta entonces en su concreta, áspera apariencia; la raza es en las palabras del cantor "estrella de sangre a flor de músculo". En los poemas del libro que titula "Nostalgias imperiales", se evoca el pasado indígena, el vencimiento incaico; se anotan aspectos tan caracterizadores de la puna como."la grama mustia, recogida, escueta"; escenas agrarias o pagano-católicas sirven de marco al indio cantor de un yaraví de sangre; a la pastora

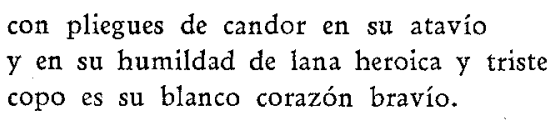

Andinas son las imágenes con que el poeta se define en el poema "Huaco":

Yo soy el llama, a quien tan sólo alcanza

la necesidad hostil a trasquilar.

El llama: la más espiritual expresión de la zoología en los Andes; el llama paciente, sumiso y -hostigado por la torpeza de los hombres- tercamente rebelde.

Mas la definición está incompleta, necesita un símbolo ambivalente, que exprese el conflicto de su alma, nacido en la literatura nuestra desde que su paisano Garcilaso de la Vega, el cuzqueño, lo hizo gemir y enorgullecerse en sus Comentarios:

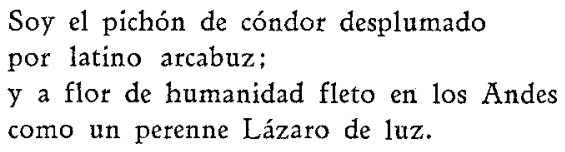

En las piedras serranas ve la santidad de no ofender ni codiciar; cuando se humanizan las mira cabizbajas, avergonzadas; ante sus ojos pasan en caravana azul, sin término.

La dulzura de la mujer andina se evoca con nostalgia en la moza de manos que planchan en actitud contrita, de ojos distraídos en algún celaje. Los dos extremos en el vivir de la mujer andina se insinúan en esa breve caracterización: las faenas obligadas - hilar, planchar, sembrar - se practican en actitud sumisa, en entrega total de la voluntad, como si la conciencia se sometiera a ancestrales 
deberes. El ensimismamiento, el simple no hacer nada, que se insinúa en ese mirar celajes; lo sorprendí un día en una indiecita sentada a orillas del Vlicanota, mirando inmóvil el correr de las aguas.

Alusiones a "cielos de puna descorazonada", la majada y e1 relincho andino, se enlazan en Trilce con el andinismo de Los $H_{e-}$ raldos negros. Pero en aquel libro lo andino es menos concreto, más nostálgico; va en la raíz del hombre inadaptado a las miserias ciudadanas, como azoramiento ante la cerrazón de los caminos que antes creyó conquistables. Sólo se hace visible a toda luz, en los poemas que son aguafuertes del hogar, en que el poeta retrocede aniñado a su casona de provincia.

11.-Temas del hogar.-La última parte de Los Heraldos negros cierra el libro con cinco canciones del hogar. Es una casona de zaguán ancho. En la sala los muebles "cansados" han envejecido mirando los cuadros de santos que cuelgan del muro. El poeta ha venido de visita después de ausencia larga. En el misterio del crepúsculo recibe vagamente, por un instante, una como anticipación fugaz del morir. El padre lo contempla desde el sillón antiguo. La madre entra y sale como una Dolorosa. Alusión a la madre pobre hispanoamericana, entristecida por los renunciamientos y los sacrificios necesarios para que sus hijos crezcan sin extremadas privaciones. El poeta encuentra en ese ambiente la inicial religiosidad, la fe en la. Providencia protectora de su niñez antes que la ciencia del mundo le llenara de tristeza.

En "Los pasos lejanos" imagina las escenas del hogar desde lejos: el padre dormido bajo apacible expresión de nobleza. La soledad es hoy más absoluta sin noticias de los hijos ausentes. E1 padre despierta con el recuerdo de la persecución y huída del hijo poeta. La madre se pasea en el huerto saboreando un recuerdo envejecido. Un hilo de ternura se tiende incontenible hacia ella en dos versos:

Está ahora tan suave,

tan ala, tan salida, tan amor.

El poeta ve avanzar su corazón a pie por los dos caminos blancos que desembocan en su aldea.

La entrañable elegía a su hermano Miguel se abriga con la misma ternura, sin que nos turbe nunca la amenaza de la sensiblería. Hay un paralelo entre el juego al esconder con que ambos se 
entretenían hasta el llanto, y el escondite sin encuentro de la muerte. "Cae sombra en el alma" del que se aburre de no ver salir al escondido. "Enereida" es glosa a los setentiocho años del padre, compuesta un día de año nuevo. Es uno de los poemas de más alcances expresivos, de más poéticas imágenes. Es ahí donde está aquel verso que tan bellamente elude la palabra muerte: " $\mathrm{Mi}$ padre es una víspera".

La quinta de las canciones del hogar es una amarga revelación autobiográfica que el poeta bautizó "Espergesia". Irreverente, Va1lejo explica su destino con estas palabras irónicamente desesperadas:

$$
\begin{aligned}
& \text { Yo nací un día } \\
& \text { en que Dios estuvo enfermo. }
\end{aligned}
$$

Con su "aire metafísico" enrarecido hasta el vacío, clama a su hermano muerto. No sabemos si el "Bueno", después del llamado, es por la respuesta o el silencio del hermano. Los versos que siguen

$$
\begin{aligned}
& \text { Y que me vaya } \\
& \sin \text { llevar diciembres, } \\
& \text { sin dejar eneros, }
\end{aligned}
$$

podrían interpretarse así: sin llevar términos concluídos en amargura, sin dejar comienzos promisores.

Su destino "tísico de luz", "gordo" de sombra, tiene una explicación ignorada por los que miran sin saber que el Misterio es

$$
\begin{aligned}
& \text { la joroba } \\
& \text { musical y triste que a distancia denuncia } \\
& \text { el paso meridiano de las lindes a las Lindes. }
\end{aligned}
$$

Es decir, de las "Iindes" evidentes a todos a las Lindes mayúsculas cerradas para el hombre.

Las abstracciones duras de Vallejo, atravesadas por negros. ventarrones, están aquí ya dando a toda su poesía, en espacios repetidos hasta el fin, ese "sabor de féretro" con que él mismo la ensombreció.

En medio de las abstracciones y novedades poéticas de Trilce, los temas de hogar reverdecen con translúcida facilidad, con nostalgia de compañía tierna o en la profunda elegía a la madre muerta 
que es el poema XXIII. El desamparo, en fin, la nostalgia del desvelo materno, de sus mandatos transformados en súplica; de la severidad cariñosa del padre, en el almuerzo que el poeta convierte en "el fecundo ofertorio de los choclos" del poema XXVIII.

La infancia interminable se actualiza en el poema III, donde un niño juega con sus hermanos Aguedita, Nativa, Miguel, en espera de las personas mayores "siempre delanteras", que no regresan a pesar de que ya está muy oscuro. La tiniebla del trasmundo se funde con la recordada, la de aquella tarde de infancia:

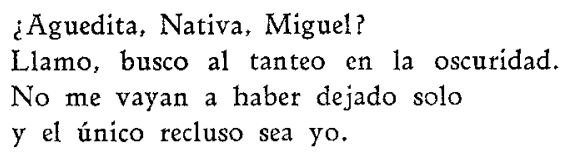

12.- - La tercera raíz poética de Vallejo es el orden social peruano y el del mundo en que le tocó vivir. Las derechas gobiernistas peruanas vieron con asombrada crueldad a todos los que, como Vallejo, se rebelaron en pensamiento $\mathrm{y}$ en acción contra un Inundo donde el pueblo se veía como instrumento ancestral de explotación. Hombre de montaña, Vallejo debió sentir un dolor físico de raíces arrancadas, tan punzante como su desconsuelo moral, al cambiar sus Andes, sus punas, y hasta su Lima, con todo lo que en ella era antitético para su existir, por la Europa que le daría la respuesta inapelable de que había llegado a la tierra a destiempo.

La llamada - por no habérsele encontrado nombre mejor- literatura proletaria surge en el Perú en Los Heraldos negros, en aquel poema que sólo tiene un antecedente en la poesía peruana: "El Mitayo", de Manuel González Prada. "Los arrieros", de Vallejo, plantea el problema del campesino en los tres versos iniciales:

\footnotetext{
Arriero, vas fabulosamente vidriado de sudor.

La hacienda Menocucho cobra mil sinsabores diarios por la vida.
}

Porque el trabajo no fué para el indio prehispánico "sinsabor", sino alegría: volver a esa situación perdida, constituyó la nostalgia y la esperanza de Vallejo. Ese tema hundido en la esencia de su propia vida es angustia de la totalidad de vidas presas, como él, en la misma injusta desesperanza: 


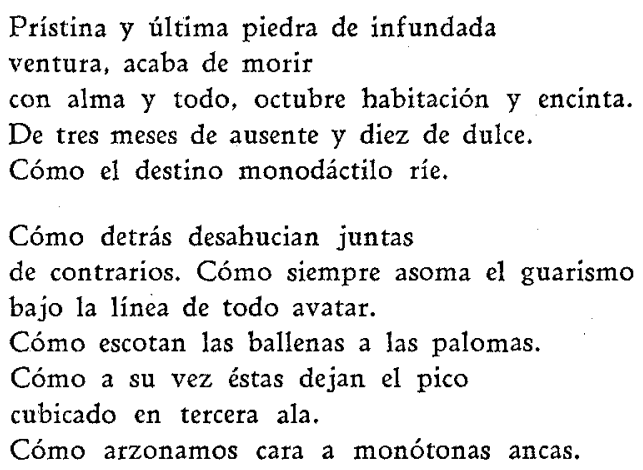

En este poema X de Trilce, el tema social, envuelto en símbolo irónico, en dramática metáfora criolla, deja a trasluz el disconformismo irremediable expresado sin rodeos en estos versos finales del poema XIV :

Pero he venido de Trujillo a Lima.

Pero gano un sueldo de cinco soles.

Vallejo ve cómo "las ballenas", símbolo de una clase, hacen pagar a las "palomas" el escote obligado. Y sabe que "arzonamos cara a monótonas ancas" como jinete en desierto sin llegadas amables.

13.-España.-El poeta Xavier Abril, peruano, amigo de Vallejo, me contó en Lima cómo siendo ambos estudiantes en Madrid en 1926, becados por el gobierno español, se marchan un día a París y desde el Café de la Regencia renuncian las cinco mil pesetas anuales de sus becas "por no poder soportar el ambiente del gobierno de Primo de Rivera”. En España, como en el Perú, Vallejo volvía a sentir la asfixia moral, dolencia incurable de su vida.

Por eso, durante la Guerra Civil española, siente por primera vez la posibilidad de una transformación que abarque en sus consecuencias al mundo; el advenimento del trabajo alegre, del pueblo feliz en un orden nuevo donde

Sólo la muerte morirá! la hormiga traerá pedacitos de pan al elefante encadenado a su brutal delicadeza; volverán los niños abortados a nacer perfectos, espaciales, y trabajarán todos los hombres, engendrarán todos los hombres, comprenderán todos los hombres! 1 
Los quince poemas que forman el libro España, aparta de mi este cáliz, son, con algunos de los Poemas humanos, la más depurada expresión lírica de Vallejo. Las desigualdades y el prosaísmo frecuente de los libros anteriores, disminuyen; el arco tendido de to poético se sostiene en tensión iluminada sobre una zona tejida con hilos de sangre y fuego de esperanza, donde se levantan estatuas de conmovedora hermosura a hombres humildes como Pedro Rojas y Ernesto Zúñiga; elegías acongojadas a ciudades heridas y oraciones donde el "Padre nuestro" y el "Dios te salve" se rezan con tangencias nuevas de divinidad. En escasos recodos la flor lila o roja de una imagen: cenizas abrazadas al cadáver de un camino; un libro retoñando de un cadáver; dolores con rejas de esperanzas; puertas elásticas del sueño.

En este libro póstumo se consuma la resurrección imperecedera de Vallejo. Porque su voz, llena de universo, de la "agonía mundial" que él mismo descubrió en la España en guerra, es hoy agonía universal en sentido geográfico cada vez más ancho; porque ese libro no es ya queja social únicamente, como los anteriores, sino un nuevo evangelio con sus mandamientos, advertencias, parábolas e incontenible amor a los humildes, y porque ese evangelio tendrá incontables discípulos sostenedores de la lumbrarada blanca de esta resurrección.

\section{Amor, pesimismo, muerte}

14.--E1 amor a la mujer es para Vallejo camino que redime, al invocar a la "dulce hebrea" en un cruce donde se funden la madre y la amada con la Virgen Madre en el episodio del descendimiento que sigue al suplicio de la Cruz. Esto sucede en Los Heraldos negros, donde el amor se asocia al "sol funeral" de los poemas y a "la hora final" transformadora de la cruz. Este enlace de amor y muerte no fué mero tema-literario, sino profética anticipación de un destino, "vocación de muerte" en el decir de Larrea, como justificación de la vida. Recuerdos de un amor destruído por la ingratitud del poeta: "bloque de hielo sobre su amapola"; encuentro con la mujer de instinto, son variantes de aquel motivo central.

El amor ingenuo de la mujer campesina aparece en "Idilio muerto", cantando con prosaísmo sentimental a la Rita "de junco y capuli", tan alejada de las princesas rubenianas. Esperó a una amada 
que no quiso plasmarse jamás "en su metafísica emoción de amor" y pensó que la angustia del amor "supervive y llora en la gran pupila de la tumba".

En Trilce, el amor aparece desdibujado por la urgencia cada vez más cruel de lo cotidiano, por abstracciones y meditaciones sobre el tiempo, la vida, la muerte. Hay una excepción: aquel poema que empieza: "Alfombra, cuando vayas al cuarto que tú sabes". Un canal le separa aquí del amor y no obstante va fuertemente asido a la muerte de su amada: la becqueriana cita de amor que sigue es una bella imagen del repetido tema:

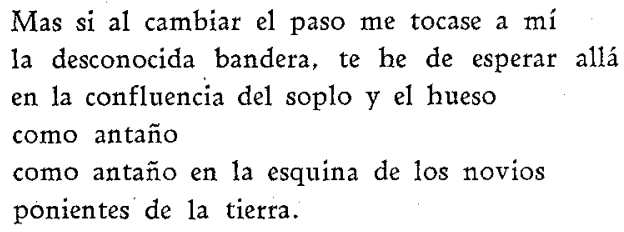

15.-El pesimismo de Vallejo nace de su desajuste social, origen de sus dudas religiosas; ve a la muerte - su principio y su fingrabada a la cabeza de sus ilusiones, según uno de sus versos. 2

El dolor de su vida le lleva a la irónica humanización de Dios en "Los dados eternos" y "Espergesia", del primer libro. El pesimismo, en Trilce, gira alrededor del paso del tiempo portador de monotonía; de la inseguridad de la suerte. Se hace una pausa cuando Dios "entreabre los sangrientos algodones y entre sus dedos toma la esperanza". Después continúa la cinta negra tendida hacia la muerte:

Fósforo y fósforo en la oscuridad, lágrima y lágrima en la polvareda. 3

El tiempo, negación de la dicha

16.-E1 tiempo como angustia, como envoltura de la desilusión, el dolor y el hastío, es en César Vallejo preocupación tenaz, que estremece su poesía de antevisiones pesimistas y de recuerdos nostálgicos. Este concepto del tiempo es evidente desde el primer libro. En "El palco estrecho", de los Heraldos negros ( $\mathrm{p}_{i} 38$ ), el poeta anuncia: 
Llueve. $Y$ hoy tarde pasará otra nave cargada de crespón; será como un pezón negro y deforme arrancado a la esfíngica Ilusión.

Las estaciones llegan para ser confidentes de su fracaso vital: el Verano, "con gran rosario de amatistas y oros", sólo alcanza a bendecir los rotos anillos de "unos novios muertos". El mes y el momento del mes en que el hecho emocional ocurre se expresan específicamente como límites para fijar el recuerdo:

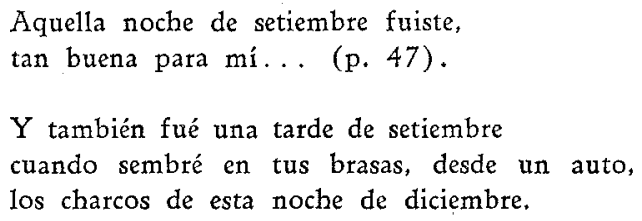

Aun a la vuelta del dichoso encuentro de amor le espera, entre los objetos cotidianos stuprimidos en su conciencia por el éxtasis, "el reloj que nos iba envolviendo en su carrete".

El mes que termina y el que comienza vieron el nacer de "malas frutas" en su tedio:

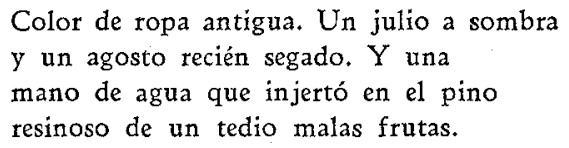

("Absoluta", p. 101).

Los nombres de los meses le sirven también de imágenes alusivas a su edad y la edad de una mujer:

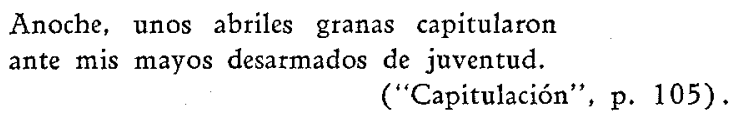

El dolor de vivir hace lenta la dimensión temporal, convierte el tiempo en espera angustiosa :

Hasta cuándo este valle de lágrimas, a donde yo nunca dije que me trajeran.

De codos 
todo bañado en llanto, repito cabizbajo y vencido: hasta cuándo la cena durará.

("La cena miserable", p. 12).

El futuro como ilusión, poblado de "caravanas de inmortales rosas", solamente lo vió el poeta, una mañana de Año Nuevo, contemplando a su padre de setentiocho años, desbordante ya de reliquias y recuerdos. Lo normal en Vallejo es sentir el tiempo como amenaza si es futuro, como limitación de fragmentos indeseables de vida:

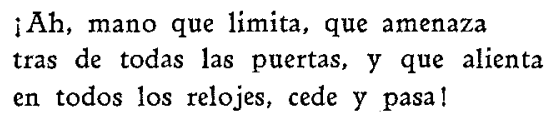

("Unidad", p. 136).

En Trilce, la conciencia del tiempo como surco movible, pero tardo, de lo cotidiano se agudiza hasta la obsesión. Ya no son los meses, sino las horas y las fechas exactas las que se apuntan en el cañamazo de Lomismo, como escribe Vallejo con su personal ortografía.

El poema XXI vuelve a mostrarnos cómo el poeta limita y funde en el transcurso de un mes las vivencias miradas con luz cruda de desilusión. Ahora es Diciembre, el señor Doce, personificado grotescamente, magro señor con aliento de infortunio, "moqueando humillación":

En un auto arteriado de círculos viciosos, torna diciembre qué cambiado con su oro en desgracia. Quién le viera; diciembre con sus 31 pieles rotas, el pobre diablo.

En un verso altera los tiempos en extraña antítesis, en que el pasado y el futuro se empujan con violencia:

E1 traje que vestí mañana no lo ha lavado mi lavandera: lo lavaba en sus venas otilinas, en el chorro de su corazón, y hoy no he de preguntarme si yo dejaba el traje turbio de injusticia. 
A mi ver, una omisión entre el pasado vestí y el adverbio mañana hace difícil ese pasaje, que puede interpretarse así: El traje que vestí entonces me lo lavaba mi lavandera en el chorro de su corazón, el que vestiré mañana será el mismo traje no lavado ya por ella, "ahora no hay quien vaya a las aguas". E1 traje limpio de ayer acaso estaba turbio de mi injusticia. Pero la que puede "azular y planchar todos los caos" no ha vuelto, se ha ausentado. El poeta duda, si ha de volver el "capulí de obrería", la trigueña bondad de la ausente.

La persistencia de estas anotaciones temporales en la poesía de Vallejo, alargarían demasiado, si me detuviera a examinarlas, este ensayo: un verano, echa nudo, es decir, termina, una etapa de tres años, "encintados de cárdenas cintas" (Trilce, p. 79); un día nace desnudo, niño, inútil para correr las leguas de su marcha sobre sus doce extremidades (Trilce, p. 161) ; voces y ciudades pasan cabalgando en un dedo tendido que señala a calva Unidad (Trilce, p. 172) ; Julio estaba entonces de nueve (Trilce, p. 194).

En España, aparta de mi este cáliz la angustia de lo temporal se anula ante el presente doloroso y prometedor. No obstante hay una expresión de tiempo, dicha con la poética luz característica del libro:

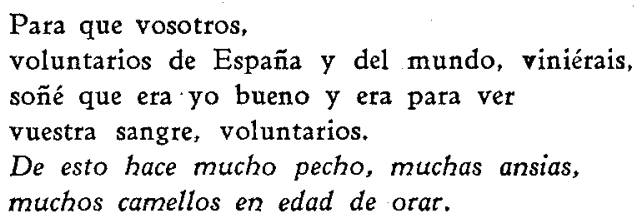

La estética de hoy ha señalado en el arte contemporáneo predominio del espacio en la atención del artista. 4 César Vallejo creó su poesía bajo el signo del tiempo, poesía de ascendente hermetismo en Trilce, que se vuelve menos difícil cuando la angustia de lo temporal cede su imperio a la fusión con el dolor humano y la esperanza de universal justicia en España, aparta de mí este cáliz.

\section{Fascinación de los números}

17.-Operaciones matemáticas, números, aparecen en la poesía de Trilce en imágenes poéticas; frecuentemente, como prosismos, 
en que los números se escriben en su forma arábiga; a veces como especulación sobre lo uno o en tangencias amorosas expresadas con el dos.

Así pasa de lo particular a lo absoluto, asido a elementos de matemáticas. Habla de una canción "cuadrada en tres silencios", de palomas que "dejan el pico cubicado en tercera ala".

La atracción amorosa es destilar del 2 en una sola tanda, apurada por ambos (Trilce, p. 59); Junio, tiene 21 uñas de estación; diciembre, 31 pieles rotas. Comienza el poema XLVIII de Trilce con este prosismo: "Tengo ahora 70 soles peruanos". En nombre de una mujer pura, "que sábía mirar hasta ser 2", va sacando lengua a las más mudas equis (Trilce, p. 203).

En España, aparta de mí este cáliz se nombran medidas matenáticas: onzas de sangre, metros de sangre, gramo del peso de la muerte.

Estas matemáticas de Vallejo añaden poco al valor lírico de su poesía; lo concreto de las cifras es choque racional que destierra los goces de la imaginación liberadora de nuestra circunstancia. Como hemos visto, el poeta se alejó después de lo desconcertante y retorcido, anclando en la sencillez de sus últimos poemas.

\section{Estética}

18. - La crítica ha visto en Trilce el comienzo de una época nueva en la lírica peruana, la ruptura con el modernismo, la expresión de la enérgica presencia andina, la nostalgia del alma india, los sentimientos universales de amor, vida y muerte transidos en Vallejo por su personal circunstancia. Estuardo Núñez asegura que todo esto se realiza "sin asimilación a tendencia extraña alguna". 5 En esencia esta afirmación es exacta, mas no en bastantes particularidades de la ortografía, la sintaxis, la imagen, el vocabulario y el matiz irónico o absurdo reveladores del conocedor inteligente de los resortes con que la poesía europea trataba de lograr la expresión de lo poético en momentos de crisis económica y social. Claro es que la poesía de Trilce tiene valores artísticos y humanos que la sostienen más allá de la insistencia en lo accesorio y circunstancial. Mas pienso que fué en los poemas escritos el año anterior a su muerte, donde Vallejo, viviendo en continuado trance lírico, re- 
cibiendo la iluminativa gracia de los místicos, da con la vestidura sin tacha para el tumulto ascendente de su corazón.

Hacía tiempo que había desechado toda falsedad dentro de su arte y hecho la autopsia del superrealismo. 6 Más que en este famoso artículo, su estética puede resumirse en las páginas escritas en 1927, "Contra el secreto profesional a propósito de Pablo Abril de Vivero". 7 Enumera allí las entonces nuevas disciplinas estéticas europeas: nueva ortografía, nueva caligrafía del poema, nuevos temas, nueva máquina para hacer imágenes, nuevas imágenes, nueva conciencia cósmica de la vida, nueva sensibilidad poética y económica.

19.-Acusa Vallejo a su generación de "impotente para crear o realizar un espíritu propio, hecho de verdad, de vida, de sana y auténtica inspiración humana". Señala con lúcida exactitud la causa de esa impotencia; "aquellas disciplinas no responden a necesidades peculiares ni han sido concebidas por libre impulso vital de quienes las cultivan". Su declaración estética sigue: pocas veces un artista ha igualado obra a credo estético con más fidelidad:

Hayl un timbre humano, un sabor vital y de subsuelo que contiene a la vez, la corteza indígena y el sustractum común a todos los hombres, al cual propende el artista, a través de no importa qué đisciplinas, teorías o procesos creadores. Dése esa emoción, sana, natural, sincera, es decir, prepotente y eterna y no importa de dónde vengan y cómo sean los menesteres de estilo, técnica, procedimiento, etc. A este rasgo de hombría y de pureza conmino a mi generación.

\section{Estilo}

20.- Simbolos.-La poesía de César Vallejo fué, desde su libro inicial, poesía difícil. Descontando las influencias de Rubén Darío y Herrera Reissig en los poemas menos valiosos de Los Heraldos negros, en este libro se establecen las vías permanentes que ha de transitar el poeta hasta morir; asoman particularidades de estilo que en 1918 son anticipaciones desconcertantes para los lectores de entonces.

Esto ocurre con los escasos símbolos en que insistió Vallejo en su poesía. Muy pocos se suman en los libros siguientes a las concreciones misteriosas que se desdoblan de algunos sustantivos de Los Heraldos negros. 
Cruz.-La pasión de Cristo mirada a través de su símbolo fué para Vallejo imagen tan inseparable de su pensar, que le acompañó como telón fijo de severos paños grises, descorrido por el poeta en múltiples alusiones hasta su identificación crística en el "aparta de mí este cáliz" de su trance mortal. Los brazos de una mujer que le ama son

cual dos blancos caminos redentores

dos arranques murientes de una cruz. 8

Las imágenes que preceden en este poema explican esta cruz: el cuerpo de la amada es un rosado Jordán que humilla la víbora del mal. E1 poeta redime con la casta luz de este amor pecados anteriores; el amor es cruz en este sentido redentor.

En el poema "Nervazón de angustia" (p. 11), el poeta se ve simbólicamente crucificado. Una mujer le ama también aquí, "La dulce hebrea" que le desclava en imaginario descendimiento:

Dulce hebrea, desclava mi tránsito de arcilla,

desclava mi tensión nerviosa y mi dolor...

desclava, amada eterna, mi largo afán y los

dos clavos de mis alas y el clavo de mi amor.

Desclávame mis clavos ioh nueva madre mia!

Sinfonía de olivos, escancia tu llorar!

$y$ has de esperar sentada junto a mi carne muerta

cuál cede la amenaza y la alondra se va!

En "Asepas" (p. 17) ofrece a Tilia sus estrofas: frutas sangrantes como sol funeral. $\mathrm{Y}$ termina el pensamiento así :

Tilia tendrá la cruz, que en la hora final será de luz.

Es decir, Tilia tendrá el dolor, el "lúgubre vino" de su vida en esas estrofas simbolizado en la cruz, transformada por la muerte en lumínico signo. Poco antes el poeta ha hablado de su "alma hereje" y en muchos poemas de este libro se muestra irreverente e irónico en consideraciones sobre la justicia divina. Pero en los más íntimos recodos del ser persiste la esperanza en la luz de la hora final. En las postrimerías de su vida, al situarse en la angustia del huerto de los olivos, esperó sin duda su pascua de resurrección. 
En el profético poema "El poeta a su amada" (p. 43), cruz es el beso de amor que descubre al poeta "un viernesanto más dulce que ese beso".

En el segundo soneto de "Nostalgias imperiales" (p. 64), la vida es "cruz idiota"; el sol muriente pide en "Oración del camino" (p. 75) : "Cuelga como un Cristo ensangrentado - mi bohemio dolor sobre su pecho"; el amor es "cruz Divina" (p. 131).

El símbolo desaparece como imagen poética en Trilce; el poeta lo vive en ese libro donde se afirma la pureza del absurdo, en aquellos versos citados antes del poema LVI, donde la angustia de los enigmas vitales se expresa en un incesante encender fósforos en la oscuridad y el dolor de vivir en la imagen: "lágrima y lágrima en la polvareda".

En España, aparta de mí este cáliz el símbolo domina en el severo telón de fondo, adelantándose alguna vez en el palo en que colgaran el madero de Pedro Rojas (p. 48) o para describir a España en guerra civil a los niños del mundo. España está "cruz y madera porque os dió la altura": España está crucificada, es la cruz, el sacrificio y el signo que lo representa, para dar la altura, lo ejemplar y heroico.

Vallejo ha dejado atrás su congoja individual para hacer suyo el dolor colectivo, el expresado en el conmovedor poema "Masa", el más hermoso del libro; para sentir el dolor de España en la muerte de Pedro Rojas y Ernesto Zúñiga; para sentir la cruz del pueblo: del yuntero y del ferroviario que en estos poemas le representan en tragedia.

Palomas, alondras.-Pablo Neruda ha explicado a Amado Alonso algunos de sus símbolos más difíciles. 9 Estas explicaciones, llaves del hermetismo nerudiano, son, para el lector imaginativo y sensible, una limitación. La interpretación personal de un símbolo poético, por lejos que esté de la intención lírica de quien lo siembra en el poema, es la decisión en una encrucijada, la salida descubierta en el laberinto donde nos dejó la audacia que representa siempre toda exégesis poética.

Las palomas, ha dicho el mismo Pablo Neruda, son en su poesía símbolo de la vida: La paloma me parece la expresión más acabada de la vida por su perfección formal. 10 Palomas es símbolo, si no insistente, por lo menos repetido en la poesía de César Vallejo, 
quien, exceptuando el símbólo cruz, no mantiene sus símbolos con abundancia de repeticiones y matices. Muchos de ellos - el mirlo de la vida, por ejemplo- aparecen una sola vez. De esos no voy a ocuparme en este estudio. Examinaré algunos de los que aparecen por lo menos tres veces en el avance de la obra total. Palomas es uno de ellos. Vallejo no podrá decirnos ya qué representaron las palomas en su poética anubarrada, donde con frecuencia vuelan cegadores relámpagos. Los que se interesan en su poesía tienen de par en par abiertas las ventanas de la conjetura. Hay que explorar en Los Heraldos negros hasta el poema "Enereida" - el penúltimo del libro-, para encontrar las palomas de César Vallejo. Es día de Año Nuevo en Santiago de Chuco. El poeta canta al amor de su padre, que pone "sus setentiocho ramos de invierno a solear". De pronto, la silueta trazada con afán de perpetuar lo que es ya tan frágil, sólo "una víspera", se interrumpe con estos versos que por el tono y pulso del creador son de hoy atnque se escribieran en 1918:

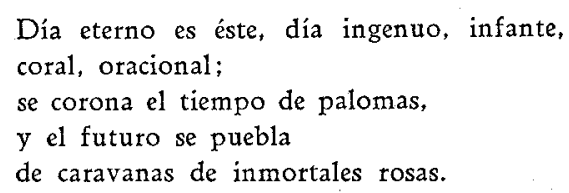

"Es Enero que canta", dice el poeta. Se corona el tiempo de palomas: es decir, de ilusiones intactas o renovadas, más ingenuas por eso, ya que pasadas borrascas no han logrado ahuyentarlas. E1 vuelo de estas palomas, en la poética de Vallejo, se ennoblece con una original belleza vencedora de la tradición.

Las palomas en Trilce representan los soñadores, los buenos, débiles ante las ballenas: los poderosos, los fuertes por su riqueza material o su audacia:

$$
\begin{aligned}
& \text { Cómo escotan las ballenas a palomas } \\
& \text { cómo a su vez éstas dejan el pico } \\
& \text { cubicado en tercera ala. }
\end{aligned}
$$

Obligados a pagar escote a la fuerza material, los buenos - palomas- dejan el pico (las ansias corporales y espirituales), elevadas a la tercera potencia, aumentadas al cubo. 
En "Himno a los voluntarios de la República" (España, aparta de mí este cáliz, pp: 28-29) las palomas vuelven a ser los débiles, por delicados o ingenuos, por la edad o la dolencia:

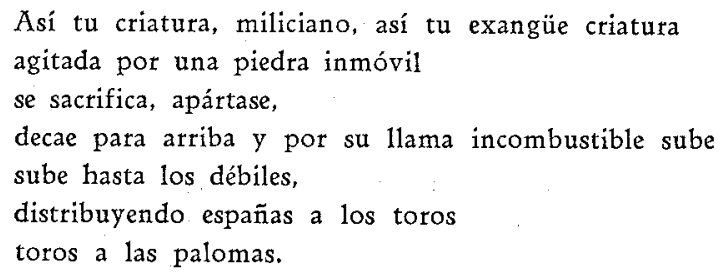

Distribuyendo en milagrosa multiplicación españas — gesto, acto, pasión privativos de España- a los toros; a la fuerza, a la agresión, y a la vez fuerza y resistencia a los débiles. Los que preguntan cómo y dónde ha muerto Ernesto Zúñiga, lo dicen expresándose "en trozos de paloma": con bondad tierna, indefensa.

Alondras, en la poesía de Los Heraldos negros, aluden a lo poético, a la exaltación del don lírico por el amor y el ansia de aventura. En "Comunión" (p. 100), dice a una mujer:

Tus pies son dos heráldicas alondras que eternamente llegan de mi ayer!

El poema "Nervazón de angustia" (p. 12) repite el símbolo, aquí como alejamiento de la posibilidad de creación, ausencia del canto ahuyentado por la persecución injusta (sicarios, cegueras de Longinos).

Acosado por una amargura que hace amargo hasta el oro del sol poniente en el valle, el poeta termina la "Oración del camino" así:

Queda un olor de tiempo abonado de versos

para brotes de mármoles consagrados que hereden

la aurífera canción

de la alondra que se pudre en mi corazón.

Hay "un nido azul de alondras que mueren al nacer" en el temblor de fiebre con que, al anochecer, el poeta se entrega a un ensoñar silencioso en la sala de su casa paterna (p. 142). 
No hay alondras ni en Trilce ni en España, aparta de mi este cáliz. Alondras es representación de intimidad lírica, de juvenil ensueño, y pertenece a la época inicial de esta poesía.

Puñal.-El ímpetu amoroso, el apasionado anhelar los dones de la vida, es en Los Heraldos negros el sustantivo puñal:

Prenderé para Tilia, en la tragedia,

la gota de fragor que hay en mis labios;

y el labio al encresparse para el beso

se partirá en cien pétalos sagrados.

Tilia tendrá el puñal,

el puñal floricida y auroral.

En el poema "Deshora" (p. 55) el poeta recuerda la pureza amada de una adolescente, cuando él mismo "hilaba aún su embrión de vida". La encontró a la vuelta del colegio, una tarde de lluvia: no era tiempo aún:

Pureza en falda neutra de colegio y leche azul dentro del trigo tierno a la tarde de lluvia, cuando el alma ha roto su puñal en retirada.

Las hincadas de la melancolía son también puñales, bebiendo la sangre del ensueño. ("Avestruz", p. 25.) En un canto a la vida ("Pagana", p. 122) el símbolo envuelve el primer significado en los versos finales:

Tal un festín pagano. Y amarla hasta en la muerte mientras las venas siembran rojas perlas de mal; $y$ asi volverse al polvo, conquistador sin suerte dejando miles de ojos de sangre en el puñal.

El poema "Los anillos fatigados" (p. 125) expresa un sentimiento muy frecuente en Vallejo; la encrucijada entre opuestos deseos: deseos de amar y deseos de morir, deseos de no haber tenido corazón. La primavera vuelve y se va. Dios se repite curvado en el tiempo. Los tres versos finales pasan del dramatismo a una ironía desesperada : 
Cuando las sienes tocan un lúgubre tambor, cuando me duele el sueño grabado en el puñal ihay ganas de quedarse plantado en este verso!

Símbolos usados con menos originalidad en Los Heraldos negros son las rosas: esperanzas como las inmortales de "Enereida" y nave que unas veces es la mujer amada ("Bordas de hielo", p. 13), otras, la poesía ("Retablo", p. 19).

Los símbolos repetidos ocurren, con dos excepciones - cruz, palomas-, solamente en el libro inicial de Vallejo. En los otros, y particularmente en España, aparta de mí este cáliz, es la riqueza de imágenes, la antitesis, las abstracciones humanizadas, lo que particulariza el estilo.

21.-Antítesis.-Este aspecto del estilo de Vallejo lo ha comentado Juan Larrea como dramática lucha por abolir la realidad. 11 Es, sin duda, el cauce que más nos dice de la "levadura de sombra y corazón" que, según el mismo poeta, era lo característico en su espíritu.

Comienzan los optestos en Los Heraldos negros, donde en el poema "Los anillos fatigados" Vallejo se describe con ganas de amar y ganas de morir, "combatido por dos aguas encontradas que jamás han de istmarse". Simultáneamente teme y ansía el amor ("Amor", p. 131) ; en su aire metafísico, hay "el claustro de un silencio - que habló a flor de fuego" ("Espergesia", p. 151). Pero es en Trilce donde la atmósfera de antítesis se hace tan densa, que a veces la sombra nos turba y el choque restallante nos deja en laberintos absurdos. Desde la primera página, en que se afirma que será tarde temprano, hasta la última, Trilce está atravesado de ideas a contrapelo que se arremolinan dejándonos interrogantes o vencidos. En el último poema, contemplando la lluvia, Vallejo piensa que se pueda secar y no quiere que esto suceda:

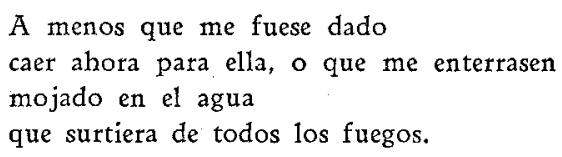

El libro se cierra con una antítesis que el lector ve columpiarse mucho tiempo agarrada a signos de interrogación: ${ }_{i} N o$ subimos acaso para abajo? 
El azoramiento del hombre serrano en la ciudad; la ineptitud para ajustarse al duro vivir miserable, es el más frecuente motivo de contradicción. Así en el poema XIV, llegado a Lima de Trujillo, el poeta concentra su dramática desesperanza en un verso: "Ese no puede ser, sido". Lo que nos parecía imposible, acontecido irremediablemente. En el poema XV se recuerda a una mujer ausente:

En el rincón aquel, donde dormimos juntos tantas noches, ahora me he sentado a caminat.

A caminar en el recuerdo, a desandar los pasos de un amor que apuró sus fuegos en días de verano y ya está lejos.

Por darle entero bien, una casa le da "entero lugar para este no saber dónde estar". Esta contradicción acusa el miedo de quien cotidianamente desconoce la dicha, de quien rechaza viviendo en seca actualidad el cruel dulzor de un buen recuerdo, que es la casa encantada donde teme entrar. Patética cobardía reveladora de insistentes fracasos, este poema pudo llamarse también como aquel otro del primer libro, "Los anillos fatigados".

22.-Imágenes.-Un grupo de imágenes en la poética de Vallejo deriva de su insistente asociación del dolor moral que nos hiere y la muerte. Los "golpes de la vida" en el poema inicial de su primer libro, son los heraldos negros que nos manda la muerte. Cada dolor nos anuncia que vamos muriendo hacia adentro: Vallejo estuvo consciente de ese morir con lucidez adivinadora. E1 desamparo del mañana en que no tendrá a quien "volver los ojos" coincide en su pensamiento con el instante en que abrirá "su grano de burla el ataúd". Esta imagen de complejas raíces acusa al desilusionado, al que vió siempre el "no puede ser, sido" para encontrar en la muerte la burla de su fracaso vital. Esta anticipada muerte se describe mejor en el poema "La voz del espejo" (Los Heraldos negros, p. 94):

Yo voy todo azorado; adelante... adelante... rezongando mi marcha funeral.

E1 sepulcro es domingo bocón y mudo que cargará con el "sábado de harapos" de su vida. 
Trilce no tiene la repetición de esta imagen, pero la desarrolla en una de las páginas, en prosa insertas con los poemas; "El no haber sido sino muertos siempre." El ser hoja seca sin haber sido verde jamás” (p. 23).

En España, aparta de mí este cáliz la asociación de dolor moralmuerte se sustituye por la idea de la muerte como sacrificio bienhechor para la felicidad del hombre futuro. Así, ante los voluntarios de la República, el poeta ve humear la alegría ante su tumba; los soldados caídos hacen la luz entornando los ojos con la muerte.

Hay, desde el primer libro, un asimiento a lo cotidiano, a lo concreto, con despreocupación por los refinamientos de vocabulario, en la creación de las imágenes y metáforas. Los "golpes de la vida" son "las crepitaciones - de algún pan que en la puerta del horno se nos quema" (p. 4). El corazón del poeta es "tiesto regado de amargura" (p. 26). Su ingratitud amorosa fué "bárbara y enorme pedrada" ("Heces", p. 50); una sepultura abierta tiene "turbia pupila de cascajo" ("Hojas de ébano", p. 69). Un joven labrador que pasa lo hace pensar en "la cruzada fecunda del andrajo" ("Mayo", p. 80). La sangre, es, en bella metáfora, "soga rubí que rechina en su cuerpo". Los desengaños de amor son "pedradas negras" ("Desnudo en barro", p. 104): Va hacia el amor "como un can herido que busca el refugio de blandas aceras" ("Amor prohibido", p. 109).

Estas metáforas e imágenes de Los Heraldos negros se mezclan todavía con otras, muy abundantes, de gusto modernista y con unas pocas de riqueza imaginativa o simbólica.

En Trilce, libro lleno de prosismos, trabajado sobre el cañamazo de "la dura vida eterna", las imágenes modernistas desaparecen. Algunas sorprenden por el esfuerzo intelectual que se aprieta en una síntesis de relaciones amables para quien las resuelve. Así, las de origen matemático que estudié antes, a las cuales puede sumarse ésta:

Dame, aire maneo, dame ir

galoneándome de ceros a la izquierda. (p. 57).

$\mathrm{Y}$ estas dos que aparecen en diferentes poemas, completándose en una exacta expresión de estados emocionales repetidos sin pausa: 
Yerra la punta del afán. (p. 60).

Esperanza plañe entre algodones. (p. 91).

La riqueza de imágenes reaparece en España, aparta de mi este cáliz; ahora lo concreto, lo material, lo cotidiano, prevalece con bella tenacidad, levantándose como lenguas de fuego en el libro encendido. Van las pasiones precedidas de dolores con rejais de esperanzas; las almas coronadas de guijarros; los voluntarios matan por los camaradas caídos, sus cenizas abrazadas al cadáver de un camino; los enemigos matan al sacerdote a cuestas con la altura tenaz de sus rodillas.

La metáfora y la imagen en Vallejo son vestigios seguros para encontrarle aun en los más extraviados recodos de Trilce, encadenado a su insatisfacción: punta del afán que yerra, esperanza herida.

23.-El adjetivo.-Desde el primer libro se nota en Vallejo un esfuerzo por adjetivar creando expresiones originales. Las primeras son inusitadas en 1918 -año de publicación de Los Heraldos negros-, porque se logran con sustantivos adjetivados: Citudad verónica, de ignotas regiones, una lágrima es novia perla.

En el poema "Los pasos lejanos", del mismo libro (p. 142), usa como predicados nominales dos nombres cargados de poética eficacia :

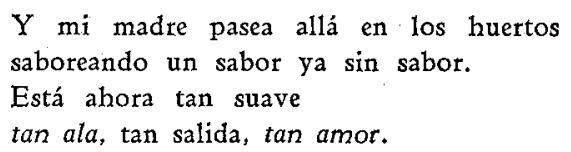

La serie de adjetivos que precisan su emoción del día de Año Nuevo, acusa también un sentido artístico que por momentos supera la medida común del estilo de entonces.

Día eterno es éste, día ingenuo, infante, coral, oracional.

En Trilce el adjetivo sigue las difíciles vías del arte de trasguerra que entre nosotros tiene un precursor conocido por Vallejo: Herrera Reissig. Encontramos aquí, en Vallejo, la trigueña bondad de una mujer, tarde inmoral, aire nene, paciencia vegetal, sillóm ayo. 
El trance de amor encendido en quemante angustia que vive el poeta durante la guerra civil española, sumerge en lírica purificación el vocabulario, enriqueciéndolo con emocional resplandor. En los quince poemas de España, aparta de mi este cáliz, todo contribuye a expresar el cardinal sentimiento que domina al poeta: su anhelo de fundirse con el dolor universal, que para él entonces es el dolor de España; de aniquilar su yo por la dicha de otros en un frenesí que le hace gritar:

\section{Por eso al referirme a esta agonía aléjome de mí gritando fuerte: \\ Abajo mi cadáver!... Y sollozo.}

Muchos de los adjetivos en el libro citado encauzan esta dación de Vallejo: El miliciano tiene huesos fidedignos y corazón con agonía mundial; el poeta mira con lobo padecer pelear al extremeño "para que todo el mundo sea un hombre"; los defensores de Guernica son suaves ofendidos, poderosos débiles.

El día en que el pueblo prendió su fósforo cautivo fué un día diurno, claro, atento, fértil. Después, soberanamente pleno, circular, "cerró su natalicio con manos electivas". Sin el proletario esfuerzo liberador el día sería antiguo, lento, colorado. Ante la grandeza sacrificada, el poeta descubre su frente impersonal. ("Himno a los voluntarios de la República".)

24.-El verbo.--En estos poemas, una sola vez, siete verbos se juntan en serie para traducir la conmoción emocional del poeta al ver cómo se marcha a morir y a matar el voluntario de España:

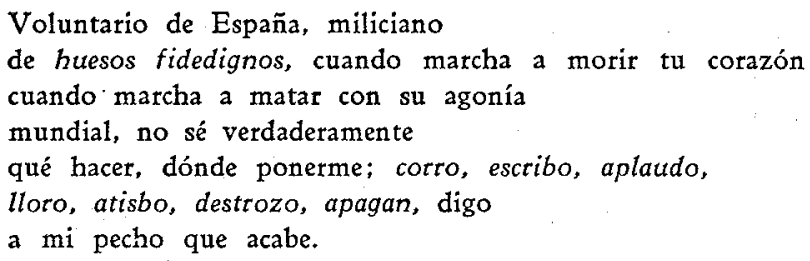

Múltiples acciones se desplazan unas a otras en rápida sucesión, revelando el atropellado desbordamiento de emociones que mueven al poeta a desear que su pecho acabe, es decir, que cese el frenesí avasallador y venga el bien sólo visto "por rejas de esperanza". 
El modo imperativo y el tiempo futuro, abundantes en los poemas, sirven a Vallejo para verter su ansia de victoria y su fe en un nuevo orden mundial ganado por el sacrificio proletario:

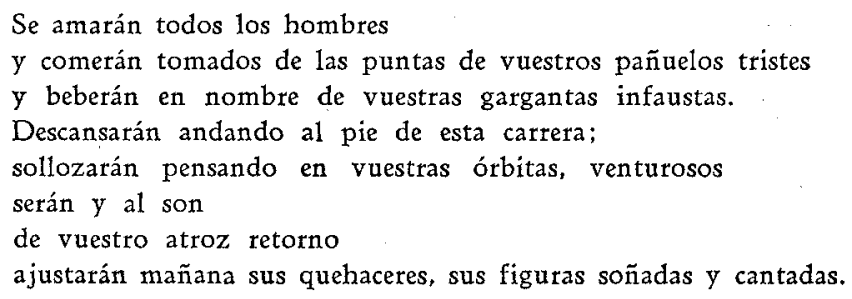

El imperativo urge, exhorta, previene, y en el poema final advierte amorosamente a España los peligros, las asechanzas de todos los poderes y todas las simulaciones que hoy más que nunca la asedian.

25.--Ritmo.--En Los Heraldos negros Vallejo no sobrepasa al ritmo métrico tradicional. Hay predominio del endecasílabo y abundancia de alejandrinos con escasos deslices a licencias rubenianas, como la supresión de la pausa central. Los demás metros típicos del Modernismo: el dodecasílabo, el eneasílabo, aparecen también alguna que otra vez. Hay hasta este verso de ritmo modernista, aunque no frecuente -Darío, Jaimes Freyre-, que resulta aún novedad en 1918:

Atrieto, vas fabulosamente vidriado de sudor.

Los otros efectos rítmicos, la insistencia en palabras y frases, por ejemplo, no ofrecen novedad dentro de los límites del instante. La tendencia prosística le lleva desde entonces a encabalgamientos sintácticos, pero estos no son vehículos, como en Pablo Neruda, del ímpetu del sentimiento, sino más bien cauces de aguas conocidas, que pueden remansar, no obstante, en una bella imagen:

Miguel, tú te escondiste una noche de agosto al alborear; pero en vez de ocultarte riendo, estabas triste... $Y$ tu gemelo corazón de esas tatdes extintas se ha aburrido de no encontrarte. $Y$ ya cae sombra en el alma. (p. 145). 
En Trilce hay aproximación al verso libre con una fuerte tendencia al endecasílabo y la frecuente reaparición del alejandrino. Estos versos de Trilce, creaciones de razonadas amarguras, movimientos intelectuales más que emocionales, ofrecen escasos efectos rítmicos de validez artística. La insistencia en palabras, la antítesis, las enumeraciones, obedecen aquí, más que a movimientos de tensión y distensión emocional, a una psicológica afirmación de tedio, de desgana, de absoluta desilusión:

Cómo detrás desahucian juntas

de contrarios. Cómo siempre asoma el guarismo

bajo la linea de todo avatar.

Cómo escotan las ballenas a las palomas.

Cómo a su vez éstas dejan el pico

cubicado en tercera ala.

Cómo arzonamos hacia monótonas ancas. (p. 46).

O el poema XIV, donde las enumeraciones, la antítesis, el redoble de los dos versos brevísimos, de una sola palabra, llegan a la misma perenne insatisfacción:

Cual mi explicación.

Esto me lacera de tempranía.

Esa manera de caminar por los trapecios.

Esos corajosos brutos como postizos.

Esa goma que pega el azogue hacia adentro.

Estas posaderas sentadas para arriba.

Ese no puede ser, sido.

Absurdo.

Demencia.

Pero he venido de Trujillo a Lima.

Pero gano un sueldo de cinco soles.

E1 ritmo como elemento poético, como expresión de lo emocional que va del apasionado delirio a la ternura, se cumple en España, aparta de mi este cáliz, testimonio de que la poesía revolucionaria puede en verdad ser poesía, cuando arranca de una generosa sinceridad, de una fusión con el dolor y la esperanza de todos los que sufren injusticia en el mundo.

,En estos poemas donde, entre la abundancia de versos libres y períodos estróficos largos, sigue aún prevaleciendo la tendencia 
al endecasílabo, y menos acusada, al alejandrino, la riqueza de efectos rítmicos se resuelve muchas veces de manera personal. Comentaré, por no alargar demasiado este ensayo, algunos ejemplos solamente, los que me parecen más expresivos por su hermosura o eficacia.

Son abundantes los efectos logrados con enumeraciones, insistiendo en elementos como para, así, si, con, dónde. Veamos éste sobre el soldado de Extremadura:

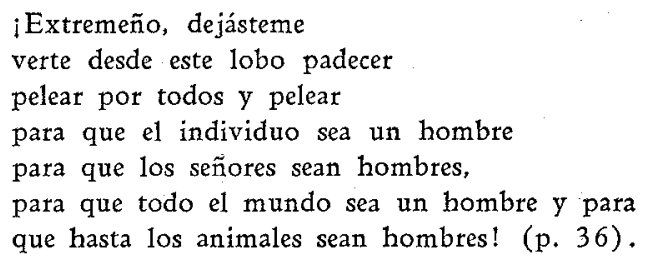

En el creciente avance del pensamiento, Vallejo radica el ser hombre en la solidaridad entrañable con los otros hombres, universal acercamiento que humaniza hasta los animales.

Hay varias enumeraciones en futuro en donde varía el verbo conservando el mismo tiempo en cadena rítmica:
Sabrán los ignorantes, ignorarán los sabios!
Serán dados los besos que no pudisteis dar!
Sólo la muerte morirá; la hormiga
traerá pedacitos de pan al elefante encadenado
a su brutal delicadeza; volverán
los niños abortados a nacer perfectos, espaciales,
y trabajarán todos los hombres,
engendrarátin todos los hombres,
comprenderán todos los hombres. (p. 30).

La enumeración puede ir de lo más débil y por eso más indefenso -el niño- a lo menos importante -el perro- en distensión emocional:

Porque en España matan, otros matan

el niño, a su juguete que se pára,

a la madre Rosenda esplendorosa,

al viejo Adán que hablaba en alta voz con su caballo

y al perro que dormía en la escalera. (p. 31). 
Con frecuencia las enumeraciones terminan con una maravillosa imagen, como en la misma página el elemento insistente por por qué deben matar los voluntarios - va introduciendo los términos enumerados hasta acabar así :

por los camaradas caidos

sus cenizas abrazadas al cadáver de un camino!

La repetición de un tema con variaciones, tan bellamente estudiada por Amado Alonso en Neruda, se da en Vallejo con mucha eficacia y movimiento. Ved cómo el tema sangre se enriquece hasta la bella antítesis final:

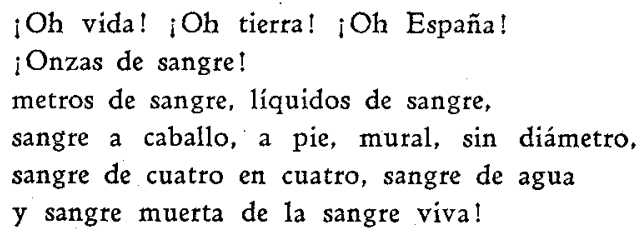

En el poema "Pequeño responso a un héroe de la República", el poeta parte de esta imagen: un libro quedó al borde de su cintura muerta.'La fantasía de Vallejo ve ese libro como un retoño del cadáver. Las palabras un libro inician los dos primeros versos con lentitud narrativa, para reaparecer en la segunda estrofa, construída con dos versos solamente, el primero con una variación indicadora del lugar del suceso; el segundo largo, de ritmo acelerado, apunta la tenaz visión núcleo del poema:

$Y$ un libro en la batalla de Toledo, un libro, atrás un libro, arriba un libro, retoñaba del cađáver.

En la tercera estrofa la imagen retorna: Quedóse el libro y nada más, para terminar la última estrofa con la repetición de la imagen, subrayada ahora por la afirmación del poeta: Yo lo vi sentidamente:

y un libro, yo lo vi sentidamente un libro, atrás un libro, arriba un libro retoñó del cadáver exabrupto. 
E1 poema "Masa", reminiscencia de la resurrección de Lázaro, €s ejemplo de tensión lírica ascendente con el mismo redoble rítmico al final de cada estrofa, excepto la última:

\title{
Pero el cadáver iay! siguió mutiendo.
}

Un hombre se acerca al muerto combatiente e intenta resucitarlo recordándole que le ama; dos se le acercan llamándole a la vida por necesitar su compañia; un grupo creciente que llega a quinientos mil se duele de la impotencia del amor ante la muerte; millones de individuos le ruegan que se quede en la vida y ante todos, el uno, y el millón, el cadáver sigue muriendo.

La progresión emocional se resuelve en la última estrofa, donde sucede el milagro de la resurrección, cuando todos los hombres de la tierra rodean al combatiente muerto, quien resucita al ver unidos, pidiéndole la vuelta a la vida, a todos los hombres.

No comentaré el "Redoble fúnebre a los escombros de Durango", parodia bellísima del padrenuestro, donde Vallejo se acoge a un perfecto isosilabismo de eneasílabos. Es una oración al padre polvo, invocado al principio del primer y tercer verso de cada estrofa, escrita en tercetos. Hay además en cuatro de las estrofas la repetición del mismo verso al principio y al fin. Estas repeticiones con las del Dios te salve siempre comenzando el segundo verso, producen un ritmo apretado de retornos seguros, como en las letanías.

No puedo terminar estos apuntes sobre el ritmo en Vallejo, incompletos y rápidos, sin mencionar la conclusión del poema que da el título al libro, realizada con el procedimiento de ritmn en cadena, introducido por el condicionante $s i$ :

\author{
¿Bajad el aliento y si \\ el antebrazo baja, \\ si la férula suena, si es de noche, \\ si el cielo cabe en dos limbos terrestres. \\ si hay ruido en el sonido de las puertas, \\ si tardo, \\ si no veis a nadie, si los asustan \\ los lápices sin punta, si la madre \\ España cae - digo, es un decir- \\ salid, niños del mundo: id a buscarla!
}


26.-Sintaxis y otras particularidades del estilo.-Vallejo tiene desde su iniciación poética algunas peculiaridades sintácticas. Una de ellas aparece ya en Los Heraldos negros, cuando sitúa las primeras palabras de un verso exclamativo fuera del lugar que le corresponde gramaticalmente:

Hoy me ha dado qué pena esa viajera. (p. 32).

Pasamos juntos. El sueño

lame nuestros pies qué dulce. (p. 35).

Suprime además Vallejo en estos casos los signos de exclamación; el emotivo impulso de las exclamaciones que vuelve así apagado, suave. De Trilce son ejemplos de este hipérbaton raro los siguientes versos:

Torna diciembre qué cambiado. (p. 67).

Y llueve más de abajo ay para arriba. (p. 67).

Una sola vez en Los Heraldos negros, Vallejo, describiendo a su madre, usa dos nombres en una serie introducidos por el adverbio tan, cuando lo correcto gramaticalmente hubiera sido precisar su pensamiento con adjetivos:

Está ahora tan suave,

tan ala, tan salida, tan amot.

Una vez, en el mismo libro, hace una atrevida omisión refiriéndose a su madre muerta: Tus puros huesos estarán harina: estarán convertidos en o reducidos a harina, a polvo.

La exclamación en España, aparta de mí este cáliz es abundantísima, expresadora de cargas emocionales que son a veces lamento, a veces grito, a veces imperativa urgencia. Aquí no se omiten los signos de exclamación: Vallejo aprovecha todos los resortes para dar paso a su credo ardiente.

E1 diminutivo, usado una rez con matiz de ironía en Trilce - la esfera terrestre del amor es el corralito consabido-, se vuelve en España, aparta de mí este cáliz surtidor de ternura:

¡Málaga sin padre ni madre ni piedrecilla, ni horno, ni perro blanco! (p. 40). 
En la misma página, Málaga bajo el fuego enemigo, se describe con aumentativos : a cielazos!

¡Málaga a golpes, a fatídico coágulo, a bandidos, a infiernazos,

$Y$ otra vez le sirve el diminutivo para referirse a Ernesto Zúñiga, muerto en la toma de Bilbao:

Tus huesecillos de alto y melancólico dibujo. (p. 58).

La familia de Ramón Collar, quien está ausente en la defensa de Madrid, reza por él, se sienta a recordarle:

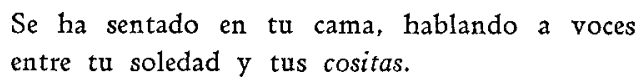

La ortografía de Vallejo en Trilce tiene extravagancias que responden a la libertad ilimitada de la poesía de post-guerra, que ya había iniciado en la anteguerra - futurismo, primeros ensayos de Apollinaire - nueva ortografía y caligrafía en los poemas.

Vallejo no solamente escribe palabras doblando y triplicando consonantes que en español no se doblan, sino formando palabras con elementos que usualmente van separados. En Los Heraldos negros dice: "El hastío - despunta en una arruga su yanó." Pero es en Trilce donde la caligrafía subraya pensamientos o emociones escribiendo palabras y versos enteros con mayúscula, donde la ortografía a menudo desconcierta sin que, en la mayor parte de los casos, le encontremos justificación. Algunos ejemplos bastarán para dar idea de este aspecto del libro:

$$
\begin{aligned}
& \text { qué la bamos a hhazer (p. 33), } \\
& \text { Vusco voluver (p. 43). } \\
& \text { Esperaos. Ya os voy a narrar } \\
& \text { todo. Esperaos sossiega } \\
& \text { este dolor de cabeza. Esperaos. }
\end{aligned}
$$

La vida es sábado de harapos. El placer que a ella nos trae nos DestieRRa. (p. 162). Unas ctantas veces repite un verso usando 
sus letras en una especie de anagrama que sin embargo no tiene sentido alguno:

\section{Oh estruendo mudo \\ ¡Odumodonuertse!}

Esta ortografía ni siquiera tiene aquel afán de embellecer la apariencia de las palabras que llevó a Darío a escribir Makehda y que todavía hace que poetas como Villaurrutia y Abril, por ejemplo, escriban Xavier, cuando desean embellecer su nombre. Si apunto este aspecto de la poesía de Vallejo, es porque tratándose de un estudio total de su poética nada tan evidente como esta particularidad formal podría omitirse. Por lo demás, el mismo Vallejo rectificó, como demostré en el comentario de su estética, estos extraviados caminos de poesía. Las invenciones ortográficas desaparecen en $E s-$ paña, aparta de mi este cáliz, donde sólo Pedro Rojas escribe sus vivas para sus compañeros con la $b$ del buitre en las entrañas.

\section{Conclusión}

Termino este estudio de la poesía de César Vallejo, insegura de haber penetrado con acierto en sus difíciles laberintos; de haber interpretado rectamente el milagro y el abismo de un alma, donde batallaron la nostalgia invencible del indio y la apasionada rebeldía de católica ascendencia española; la delicadeza de su destino de artista y el impacto brutal de los tiempos desencadenados en tragedia en que vivió hasta "morir de universo". He cumplido al menos una promesa que hice a mis amigos del Perú y a mí misma hace seis años, y el cumplimiento de una promesa es siempre afirmación, sosiego y acrecentamiento de la voluntad. Válganme estas razones como disculpa de ceguedades y torpezas.

Concha Meléndez, Universidad de Puerto Rico. 


\section{NOTAS}

1 "Himno a los voluntarios de la República", en España, aparta de mí este cáliz, p. 30 .

2 "Imagen española de la muerte". Ibid., p. 54.

3 Poema LVI en Trilce. Madrid, 1930, p. 182.

4 Leopoldo Hurtado, Espacio y tiempo en el arte actual. Buenos Aires, Editorial Losada, 1941 , p. 77.

5 Estuardo Núñez, Panorama actual de la poesía petuana. Lima, Editorial Antena, 1938, p. 18.

6 "Autopsia del superrealismo", en Nosotros, Buenos Aires, Vol. 67, enero de 1930.

7 "Contra el secreto profesional a propósito de Pablo Abril de Vivero", en Repertorio Americano, San José, Costa Rica, 15 de agosto de 1927.

8 "Comunión", en Los Heraldos negros, p. 10.

9 Amado Alonso, Poesía y estilo de Pablo Neruda. Buenos Aires, Editorial Losada, 1940.

10 Ibid., p. 193.

11 Juan Larrea, "Memoria de César Vallejo", en Garcilaso, Lima, octubre de 1940, Año I, núm. 1, p. 21.

12 Amado Alonso, op. cit., p. 83. 
